\title{
Effectiveness of Systemic Text Analysis in EFL Writing Instruction'
}

\section{Efectividad del Análisis de Texto Sistémico en la Enseñanza de Escritura de EFL}

\author{
Ender Velasco Tovar ${ }^{2 *}$ \\ British Council, Bogotá, Colombia
}

\begin{abstract}
This action research study investigates the effectiveness of a model based on the theory of systemic text analysis for the teaching of EFL writing. Employing students' pieces of writing and a teachers' survey as data collection instruments, the writing performance of a group of monolingual intermediate level adult students enrolled on a private EFL school in Bogota, Colombia was gauged before and after the model implementation. The results suggest that the proposed model is somewhat effective for the teaching of factual EFL writing and that it has a seemingly positive effect on the writing performance of EFL students in terms of cohesion and coherence at the paragraph level.
\end{abstract}

Keywords: EFL writing, cohesion, coherence, thematic patterns, text analysis.

\section{Resumen}

Este estudio de investigación acción explora la efectividad de un modelo basado en la teoría de análisis sistémico de texto para la enseñanza del inglés como lengua extranjera. Se utilizaron escritos de estudiantes y se aplicó una encuesta a los profesores como instrumentos de recolección de datos para determinar el nivel de escritura de un grupo de estudiantes adultos de nivel intermedio, matriculados en una escuela privada de EFL en Bogotá, Colombia. Los resultados sugieren que el modelo propuesto es hasta cierto nivel efectivo para la enseñanza de la escritura objetiva de EFL y parece tener un efecto

\footnotetext{
1 Received: May 30, 2016 / Accepted: October 6, 2016

2 velasco_ender@yahoo.co.uk
} 
aparentemente positivo en el rendimiento de la escritura de los estudiantes de inglés como lengua extranjera en términos de cohesión y coherencia a nivel de párrafos.

Palabras clave: escritura EFL, cohesión, coherencia, esquemas temáticos, análisis de texto.

\section{Resumo}

Este estudo de pesquisa ação explora a efetividade de um modelo baseado na teoria de análise sistêmica de texto para o ensino do inglês como língua estrangeira. Utilizaram-se escritos de estudantes e aplicou-se uma enquete aos professores como instrumentos de coleta de dados para determinar o nível de escritura de um grupo de estudantes adultos de nível intermédio, matriculados em uma escola particular de EFL em Bogotá, Colômbia. Os resultados sugerem que o modelo proposto é até certo nível efetivo para o ensino da escritura objetiva de EFL e parece ter um efeito aparentemente positivo no rendimento da escritura dos estudantes de inglês como língua estrangeira em termos de coesão e coerência ao nível de parágrafos.

Palavras chave: escritura EFL, coesão, coerência, esquemas temáticos, análise de texto. 


\section{Introduction}

7 he inability of some EFL students to acquire high levels of proficiency in L2 writing has been the subject of heated discussions amongst teachers across many EFL contexts, resulting in harsh critiques made by various professionals in terms of disorganisation and lack of coherence found in EFL writing (Horner \& Min-Zhan, 1999; Keck, 2006; Olivas \& Li, 2006; Wall, Nickson, Jordan, Allwright \& Houghton, 1988; Woodrow, 2006; and Yu, 2009).

Linking theoretical concepts from systemic functional linguistics to the EFL classroom, this study aimed to investigate the effectiveness of a model based on the theory of Systemic Text Analysis (Bloor \& Bloor, 2013) for the teaching of EFL writing. This model entailed the application of three thematic patterns through text analysis tasks to a class of intermediate adult students as part of their writing instruction over a period of four weeks. Students were first introduced to the basics of systemic functional linguistics theory and were asked to carry out theme and rheme analyses of three different texts. These included a biography divided into two parts, and a text about different types of paint. Each analysis was used as the platform to introduce three different thematic patterns, namely continuous, zigzag and split. Students then carried out further analysis of a text about poverty, in which they had to identify themes-rhemes and a mixture of thematic patterns. Finally, they were asked to write their own paragraph collaboratively.

In order to investigate the effectiveness of such a model, the study was based on these two research questions: To what extent is the proposed model effective for the teaching of factual EFL writing? and Does the proposed model have any effect on the writing performance of EFL students in regard to organisation of ideas at paragraph level? The results suggest that the proposed model is effective to some extent for the teaching of EFL writing and that it seems to have a positive effect on the cohesion and coherence of students' paragraphs in factual pieces of writing.

\section{Literature Review}

\section{Theme and Rheme}

Based on systemic functional linguistics, a text is said to have cohesion and coherence when the language in it is organised and connected through structural and cohesive components. Within structural components, Halliday and Mathiessen (2004) define theme in a clause as "the starting-point for the message: it is what the clause is going to be about" (as cited in Eggins, 2004, p. 299). On the other 
hand, rheme is identified as "everything that is not the theme" (p. 300). In other words, it could be said that the former is the subject of a clause which tends to be known because it has been mentioned before or can be worked out from the immediate context, and the latter provides new or unknown information which helps develop the topic or idea. The table below exemplifies this.

Table 1. Sample sentence broken down into unmarked theme and rheme

\begin{tabular}{|c|c|}
\hline Theme & Rheme \\
\hline Marianne North & was born in Hastings in 1830. \\
\hline
\end{tabular}

The example above can be considered as unmarked theme. However, on many occasions, proficient writers make different choices when packing information in a clause. While an unmarked theme indicates a common choice made by writers and equality of meaning in a clause, a marked theme denotes an uncommon choice and unusual balance of meaning. Readers are prompted to the fact that meaning may need to be made from the context of the clause in a different way. The table below exemplifies this.

Table 2. Sample sentences broken down into marked theme and rheme

\begin{tabular}{|l|l|l|}
\hline \multicolumn{1}{|c|}{ Marked Theme } & \multicolumn{1}{|c|}{ Rheme } & \\
\hline As for Marianne North, & $\begin{array}{l}\text { she was born in Hastings in } \\
1830 .\end{array}$ & \\
\hline It & was in Hastings & $\begin{array}{l}\text { Where Marianne North was } \\
\text { born. }\end{array}$ \\
\hline
\end{tabular}

\section{Thematic Patterns}

This refers to the different ways writers tend to introduce, package and organise information at paragraph level in pieces of writing (e.g. factual) in order to give these cohesion and coherence. Bloor and Bloor (2013) identify three main thematic patterns. In a continuous thematic pattern, the clauses within the same paragraph begin with what was identified as theme in the first clause. This pattern may be repetitive, but it gives a clear focus to the writing. The figure below illustrates this. 


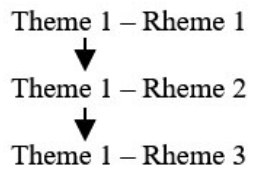

Figure 1. Continuous thematic pattern (Bloor \& Bloor, 2013, p. 90)

This pattern may look like this:

Marianne North was born in Hastings in 1830. She revealed a talent for drawing and developed a fascination for travelling from her father at an early age. She devoted the reminder of her life to painting after her father's death in 1869.

(Text adapted from Royal Botanic Gardens Kew).

In a zigzag thematic pattern, the clauses within the same paragraph begin with an item that was identified as part of the rheme in the first clause. This pattern gives more cohesion to the writing when a change in subject ought to be introduced, as opposed to when new themes are brought externally i.e. from outside the text. The figure below illustrates this.

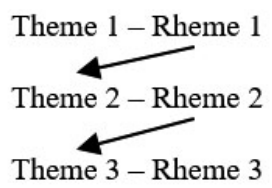

Figure 2. Zigzag thematic pattern (Bloor \& Bloor, 2013, p. 91)

This pattern can be exemplified as follows:

Miss North travelled widely, frequently enduring considerable discomfort in order to paint flowers in their natural habitats. The habitats she portrayed were colourful and vivid, often including representations of flowers and wildlife. Her paintings achieved a high level of artistic competence, despite her lack of formal training. Her lack of training, however, did not hinder her natural talent and speed for drawing and painting, sometimes completing a picture in one day.

(Text adapted from Royal Botanic Gardens Kew). 
Lastly, in a split thematic pattern, an item that was identified as part of the rheme in the first clause is divided systematically. Subsequent clauses within the same paragraph are developed around such item, providing a pattern that gives clear organisation to the writing. Cohesive devices such as firstly, secondly, then, etc. can be added to prompt readers even further. The figure below illustrates this.

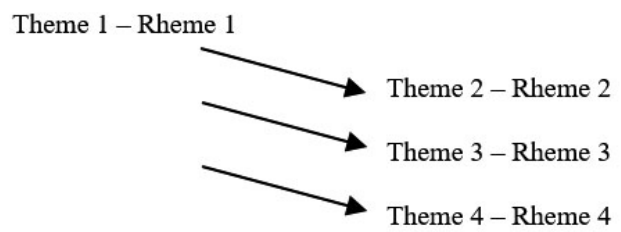

Figure 3. Split rheme pattern (Bloor \& Bloor, 2013, p. 92)

The text below exemplifies this pattern.

Many amateur artists first learn about three types of paint and the media in which pigments are suspended. Oil paint is the product of pigments that are bound with a medium of drying oil. This oil is a mixture of linseed boiled with pine resin. Pastel paint is a medium in the form of a stick, consisting of a pure powdered pigment and a binder. This binder has neutral hue and low saturation. Acrylic paint is fast drying paint containing a pigment embedded in an acrylic polymer emulsion. This emulsion can be diluted with water, but it becomes water-resistant when dry.

(Text adapted from Doerner, 1949)

\section{Text Analysis in the EFL Writing Classroom}

It has long been recognised that the integration of reading as the basis for subsequent analysis can develop students' awareness of writing subskills or "top-down and bottom-up strategies" (Davies, 1988, p. 134). There is also a wealth of evidence suggesting that EFL students' writing performance is likely to improve when performing classroom tasks that involve reading and writing (Cheng, 2008; Connor \& Farmer, 1990; Cumming \& Riazi, 2000; Flowerdew, 2000; Kongpetch, 2006; Sidaway, 2006; Yuan-Shan \& Shao-Wen, 2011), particularly within the genre-based approach to teaching EFL writing. These tasks usually entail guided practice using genre templates through which the teacher scaffolds lexico-grammar and discoursal features found in texts. Also, some authors have found a positive relationship between L2 teaching- 
learning and linguistics theory instruction (Cuenca; Pastor, cited in Rojas, 2014, p. 160).

However, there is little information about research on the application of thematic patterns analysis with EFL classrooms and its effectiveness in relation to writing instruction. Therefore, this allows room for more specific studies, perhaps of a qualitative nature, to determine if systemic text analysis instruction translates into either progress or regress in terms of students' writing skills. This has major implications for EFL writing teachers in regard to the way the teaching of writing is approached and the variety of activities that have to be brought into the classroom.

\section{Methodology}

\section{Research Design}

The assumption in this study is that the application of the proposed text analysis model could potentially contribute to an increase in the writing performance of EFL students, specifically in relation to organisation of ideas at paragraph level. Therefore, the study set out to answer the following research questions: To what extent is the proposed model effective for the teaching of factual EFL writing? and Does the proposed model have any effect on the writing performance of EFL students in regard to organisation of ideas at paragraph level?

In order to find the answers to these two questions, this study compared students' pieces of writing before and after an intervention based on a model using Bloor and Bloor's (2013) thematic patterns described earlier. The intervention took place across four different text analysis tasks, and a subsequent collaborative writing task.

Due to its purpose, short time scale, practical nature, researcher involvement and immediate application to classroom issues, this study can be framed within the first cycle of an action research approach (Bell, 2010). This strategy was chosen based on factors such as suitability, feasibility and ethics, bearing in mind that other strategies such as experiments or case studies would not be viable (Denscombe, 2010).

\section{Context and Participants}

This study took place in a private English language school in Bogota, Colombia. The participants were a monolingual (Spanishspeaking) group of 12 adult students enrolled on an intensive intermediate level general English course (B2) over a period of four weeks. During the study, participants received about ten hours of instruction per week under the Communicative Language Teaching 
(CLT) approach. The class was made up of seven females and five males between the ages of 20 and 39. They all were either working or studying at the time of the study, and their motivations for learning English included personal development, further studies, and better employability prospects. The writing instruction proposed in the model as part of this study was embedded within the main course instruction and was not delivered as separate sessions. Consent forms were signed and dated by each participant before taking part in the study.

Twelve teachers working at the same language school also took part in the study. Their L1 was English, and they had a minimum of two years post-CELTA teaching experience in various contexts. Their sole role was to give an overall assessment of the participants' writing performance.

\section{Data Collection Instruments}

Data collection instruments included two sources: students' artefacts and a teachers' survey.

Students' artefacts. In order to gauge participants' progression or regression in terms of writing performance, students' pieces of writing were collected before and after the model implementation, in Weeks 1 and 4, respectively. These included factual paragraphs around three topics, namely: computer types, the seasons, and kinds of holiday accommodation. Students were given 30 minutes to carry out the tasks which had a word limit of 120-180 words.

The twelve students were divided into three groups of four. Each group was then randomly assigned one of the three topics for the first task. The students wrote about the same topic for the second writing task after the model implementation. Once copies of handwritten work had been made, students were asked to type in their pieces of writing and submit the soft copies. Soft copies were cross checked against hard copies to make sure that no changes were made to the former.

Sampling was carried out using a non-statistical approach. That is, each participant in each of the three groups was assigned a number from one to four. These numbers were then written on separate cards and one participant from each group was randomly drawn to be measured in terms of his/her writing performance. In total, three samples, i.e. students were selected. Although this might have caused issues with data reliability, the decision to select only three samples for the analysis was made purely based on the nature of the action research study. In other words, the time was too short (4 weeks) and the financial and human resources were limited (involvement of third parties to carry out analyses of thematic patterns was not viable). 
Teachers' survey. In order to offer more consistency to the study, the twelve teachers were asked to assess each piece of writing employing a five-point Likert scale based on the following question: Understanding cohesion and coherence as the organisation of ideas, clear focus in the development of ideas, and linking between ideas through cohesive devices, how would you assess the cohesion and coherence of the following pieces of writing? 1) Very poor, 2) Poor, 3) Acceptable, 4) Good, or 5) Very good? Please give a reason (or reasons) for your choices. This, by all means, was not a complex and exhaustive statistical procedure. On the contrary, it was purely an internal peer survey exercise.

\section{Data Analysis and Interpretation}

Students' artefacts. A qualitative analysis was employed. Writing samples from the three selected students were coded to guarantee anonymity and then analysed for theme, rheme and thematic patterns (Bloor \& Bloor, 2013) on both instances, before and after the model implementation.

The implementation of the proposed model for the teaching of factual EFL writing was carried out in Weeks 2-3. The teacher-researcher implemented a workshop in which participants worked collaboratively through three text analysis tasks. Students analysed three texts for theme and rheme. These analyses were the basis to introduce the continuous, zig-zag, and split thematic patterns. To follow up this session, students were asked to bring one example of the three patterns found in authentic material written in English, for example, magazines, newspapers, books, and so on. One week later, the teacher-researcher incorporated a second workshop in which students had to carry out a theme-rheme and thematic pattern analysis of a different text about "types of poverty." Then, students were asked to write a short collaborative paragraph on a topic of their choice in which one thematic pattern or a mixture of these was included. Students shared the paragraphs and the teacher provided feedback.

Artefacts before the model implementation were coded as 1a, $1 \mathrm{~b}$ and $1 \mathrm{c}$ whereas those afterwards were coded as $2 \mathrm{a}, 2 \mathrm{~b}$ and $2 \mathrm{c}$, assigning one letter to each of the three writing topics, a) computer types, b) the seasons, and c) types of holiday accommodation. In order to measure students' writing performance, analyses were carried out grouping samples before and after the model implementation according to the three topics given to the students, i.e. computer types (1a-2a), the seasons (1b-2b), and types of holiday accommodation (1c-2c). The paragraph analyses were carried out by the teacher-researcher. 
As the main concern in this study was the organisation of ideas at the paragraph level, grammar, spelling and punctuation errors were not taken into consideration. However, these were highlighted in grey during the analyses.

Teachers' survey. The 12 teachers were divided into three groups of four people, and each group was presented with a pair of samples e.g. $1 \mathrm{a}-2 \mathrm{a}$, or $1 \mathrm{~b}-2 \mathrm{~b}$, or $1 \mathrm{c}-2 \mathrm{c}$ so they could give an overall assessment of cohesion and coherence within the Likert scale. An important aspect during the data collection for this part of the process was that teachers were not told that the pieces of writing had been written by the same student, so they would not have any preconceptions about which samples had been written before and after the teaching intervention. They were asked to disregard grammar, vocabulary, punctuation and spelling mistakes during the assessments, and specifically focus on aspects of cohesion and coherence. Teachers were given the opportunity to give reasons for their assessment. Their qualitative comments were grouped into four categories coded for analysis: 1) organisation of ideas, 2) clear focus on development of ideas, 3) linking between ideas through cohesive devices, 4) other reasons. Teachers' assessments of samples were collected, organised and tabulated. As suggested when working with ordinal data (Denscombe, 2010), the quantitative data from the peer survey was analysed by working out the mode (i.e. the most common answer) as a measure of central tendency, and the range as a measure of dispersion of data. Quantitative data was contrasted to gauge any kind of progression or regression in the students' writing performance.

\section{Results}

This study was founded on general issues related to disorganisation and lack of coherence found in EFL writing, and on the assumption that the application of a model based on the application of three thematic patterns through text analysis tasks could potentially contribute to an increase in the writing performance of EFL students. The research was designed around two questions: To what extent is the proposed model effective for the teaching of factual EFL writing? and Does the proposed model have any effect on the writing performance of EFL students in regard to organisation of ideas at paragraph level?

\section{Analyses of Samples 1a and 2a}

The contrast of analyses $1 \mathrm{a}$ and $2 \mathrm{a}$ showed that the proposed model is to some degree effective for the teaching of factual EFL writing, and that students' writing performance is likely to improve when carrying out tasks involving text analysis followed by writing. 
In general, analysis 1a showed a rather disjointed paragraph with the majority of themes brought externally i.e. not related to previous themes or themes mentioned earlier in the text. It had too many external themes $(2,4,5,6,7,8$ and 10$)$, which prompted a lack of internal cohesion and coherence within the piece of writing.

The word count in analysis 1a tallied 170 words. There were a few internal links between themes. For example, only themes 2-3 and 10-11 followed a continuous pattern, and rheme 8 - theme 9 followed a zigzag pattern. Rheme 2 showed a split thematic pattern including various computer types i.e. "[...]desk computers,notebooks, ultrabooks[...]", but only one of these was subsequently developed later i.e. "a desk computer" (theme 5). This is shown in Table 3 below.

\section{Table 3. Analysis of sample 1a}

\begin{tabular}{|c|c|c|c|}
\hline No & Theme & Rheme & Pattern \\
\hline 1 & The first computers & $\begin{array}{l}\text { used to be huge, as big as a whole room, and not } \\
\text { very impresive in terms of power, but now }\end{array}$ & \\
\hline 2 & We & $\begin{array}{l}\text { have different types of computers, such as desk computers, } \\
\text { notebooks, ultrabooks and in a couple of year maybe }\end{array}$ & external theme \\
\hline 3 & we & will see quantum computers. & Continuous \\
\hline 4 & $\begin{array}{l}\text { Every kind } \\
\text { of computer }\end{array}$ & has its own advantages and disadvantages, for instance, & \\
\hline 5 & a desk computer & is more powerful and customisable than notebooks, but & split from rheme 2 \\
\hline 6 & You & $\begin{array}{l}\text { can't carry your desk PC in your bag which is very } \\
\text { important if you are a university student or a bussiness man. }\end{array}$ & external theme \\
\hline 7 & Nowadays, there & are computers for everyone and every lifestyle and & \\
\hline 8 & the companies & $\begin{array}{l}\text { do great efforts to bring to life new funcionalities like } \\
\text { touchscreens, fingerprint recognition and 3D force touch } \\
\text { on the pad track. }\end{array}$ & external theme \\
\hline 9 & $\begin{array}{l}\text { Some of these } \\
\text { funcionalis }\end{array}$ & could have sound like fiction on the past and now are a reality, so & zig-zag \\
\hline 10 & We & do not know what is going to be next but & external theme \\
\hline 11 & We & $\begin{array}{l}\text { can be sure that the next type of computers will be better } \\
\text { than ever. }\end{array}$ & Continuous \\
\hline
\end{tabular}

In contrast, although its word count was lower, analysis 2 a seemed a more compact paragraph with plenty of themes linked internally resulting in better organisation within the paragraph. The word count in analysis 2 a tallied 134 words. Compared to analysis 1a, there were more internal links between themes and fewer themes brought externally. For 
instance, themes 1-2 followed a continuous pattern, then an external theme i.e. "everyone" (theme 3 ) was brought in. Rheme 4 was then split into "3 main types of computers", subsequently developed in rheme 5 "desk PC", theme 9 "laptops" and rheme 12 "ultrabooks". Each split was well developed later. For example, rheme 5 and themes 6-8 were linked through a zigzag-continuous pattern, themes 9-10 showed a continuous pattern, and rheme 12 and themes 13-14 followed a zigzagcontinuous pattern. This is shown in Table 4 below.

\section{Table 4. Analysis of sample 2a}

\begin{tabular}{|l|l|l|l}
\hline No & Theme & Rheme & Pattern \\
\hline 2 & Computers & have changed over the time. At the begining & \\
\hline 3 & Nowadays everyone & can use [them] based on their necesities. & Continuous \\
\hline 4 & There & are 3 main types of computers. & external theme \\
\hline 5 & The most common & is the desk PC, & \\
\hline 6 & this machine & is not portable but & split 1 from rheme 4 \\
\hline 7 & It & is the best choice to work with large programs and & zig-zag \\
\hline 9 & In contrast, laptops & are portable and easy to carry everywhere but & split2 from rheme4 \\
\hline 10 & They & have a lower capacity and are less adaptable. \\
\hline 11 & People & $\begin{array}{l}\text { use them to do task like sending emails, searching } \\
\text { on [the] internet and other daily assignments. }\end{array}$ & Continuous \\
\hline 12 & Finally there & are ultrabooks which have the same caracteristics of laptops, but & split3 from rheme4 \\
\hline 13 & They & are slimmer and lighter and unlike laptops & zig-zag \\
\hline 14 & They & don't have CD-room and internet port. & Continuous \\
\hline
\end{tabular}

These results might be worthy in the sense that the proposed model could potentially be a valuable writing aid for teachers whose students find it hard to be precise and concise when writing within a word limit. Also, these findings seem to contribute to other research in which a positive relationship between L2 teaching-learning and linguistics theory instruction has been found.

\section{Analyses of Samples $1 \mathrm{~b}$ and $2 \mathrm{~b}$}

The contrast of analyses $1 b$ and $2 b$ corroborated the view of various professionals who have criticised the disorganisation and lack of coherence found in EFL writing. On the whole, analysis $1 \mathrm{~b}$ showed a fairly good use of internal links, but too many shifts in themes resulted 
in a paragraph with a loose focus and a piece of writing that lacked coherence in relation to the task in hand i.e. "the seasons."

The word count in analysis $1 \mathrm{~b}$ tallied 132 words. There were some internal links between themes, but the choice of themes assumed familiarity of the reader with the seasons, so these were not explained or developed appropriately. This can be exemplified by rheme 1 which mentioned the phrase "four seasons," but only two seasons were mentioned later in rhemes 4 and 5. Although themes 2-3 showed a continuous pattern, seasons would be expected to appear as themes as opposed to rhemes, but this was not the case. Instead, the writer chose to use marked themes beginning sentences 4-5 and 8-9 with the impersonal pronoun "it" as the theme. Then, "They" (theme 10) was linked back to "[...] these countries [...]" (rheme 9). Last, an external theme ("Most people" - line 11) was brought in and linked to themes 12-14 through a continuous pattern ("they-they-they"). This is shown in Table 5 below.

Table 5. Analysis of sample $1 \mathrm{~b}$

\begin{tabular}{|l|l|l|l|}
\hline $\mathbf{N} 0$ & Theme & Rheme & Pattern \\
\hline 1 & There & are four seasons. & \\
\hline 2 & Each season & cover 3 months in a year. & \\
\hline 3 & The seasons & depends on the place you are in. & continuous \\
\hline 4 & It & is common [that] while in one country it is winter, & split 1 from rheme 1 \\
\hline 5 & at the same time [it] & could be summer in another. & split 2 from rheme 1 \\
\hline 6 & But seasons & do not take place all over the world. & \\
\hline 7 & There & are some countries where the weather changes & \\
\hline 8 & In some others, it & rains most of the time. & $\begin{array}{l}\text { happens beacause these countries are near to the Ecuador's } \\
\text { line or }\end{array}$ \\
\hline 9 & It & are close to the poles. & zig-zag \\
\hline 10 & They & prefer cities where they can have the 4 seasons, because & external theme \\
\hline 11 & Most people & can buy different kinds of clothes, Also, & continuous \\
\hline 12 & They & are certain about what the weather is going to be like. & continuous \\
\hline 13 & They & can make especial plans for each season. & continuous \\
\hline 14 & And finaly, they &
\end{tabular}

On the other hand, analysis $2 b$ carried out after the model implementation seemed to have better cohesion and coherence due to a larger amount of internal links and more sustained themes throughout the piece of writing. 
The word count in analysis $2 \mathrm{~b}$ tallied 161 words. Compared to analysis $1 b$, there was more consistency in terms of greater number of internal links between themes and themes. For example, rheme 1 showed a split thematic pattern in which the four seasons were included i.e. "[...] winter, summer, autumn and spring.". Each of these was developed later in themes 3, 7, 10 and 12. The "winter" (theme 3) was developed through a continuous pattern ("It" - theme 4), and themes 5 and 6 were linked to their previous rhemes through zigzag patterns i.e. "[...] variable weather." in rheme 4 and "[...] snow." in rheme 5. The "summer" (theme 7) was developed through two consecutive continuous patterns (themes 8-9). The "autumn" (theme 10) was also expanded similarly in theme 11. The "spring" (theme 12), the last split from rheme 1, was developed through two consecutive continuous patterns (themes 13-14) and a zigzag one linking rheme 14 "[...] weather conditions." and theme 15 "These conditions." This can be seen in Table 6 below.

Table 6. Analysis of sample $2 \mathrm{~b}$

\begin{tabular}{|c|c|c|c|}
\hline No & Theme & Rheme & Pattern \\
\hline 1 & One year & has four seasons such as winter, summer, autumn and spring. & \\
\hline 2 & Each season & $\begin{array}{l}\text { has a three month duration, Although in the countries close } \\
\text { to Ecuator there are no seasons at all. }\end{array}$ & \\
\hline 3 & Winter & is the coldest season. & split 1 from rheme 1 \\
\hline 4 & It & has variable weather. & Continuous \\
\hline 5 & The weather in Winter & can include low temperatures, wind and snow. & zig-zag \\
\hline \multirow[t]{2}{*}{6} & Snow during winter & allows children to have fun making snow angels, & zig-zag \\
\hline & in some countries & snowman and [having] snowbattles. & \\
\hline 7 & Summer & is the favorite season for most people because & split 2 from rheme 1 \\
\hline 8 & It & has sunny days with amazing weather. & Continuous \\
\hline 9 & It & let people to do more activities outside. & Continuous \\
\hline 10 & Autumn & $\begin{array}{l}\text { is when trees fall their leaves and the landscape start getting } \\
\text { colorful with diferent tones like yellow, brown, orange and red. }\end{array}$ & split 3 from rheme 1 \\
\hline 11 & It & is usually windy and rainy. & Continuous \\
\hline 12 & Spring & is the last one of the seasons. & split 4 from rheme 1 \\
\hline 13 & This season & $\begin{array}{l}\text { is where flowers grow and all animals awake from their } \\
\text { hibernation. }\end{array}$ & Continuous \\
\hline 14 & It & is a season with mild weather conditions. & Continuous \\
\hline 15 & These conditions & are perfect for outdoor picnics and laisure activities. & zig-zag \\
\hline
\end{tabular}

Of course, the word limit in the paragraph after the model implementation was greater, which allowed the student more room to 
extend ideas further. However, this could mean that the proposed model based on thematic patterns analyses carried out in the classroom is somewhat effective for the teaching of factual EFL writing in the sense that teachers can point out alternatives students could use to develop and extend their ideas better without losing the focus in paragraphs.

\section{Analyses of Samples 1c and 2c}

The contrast of analyses $1 \mathrm{c}$ and $2 \mathrm{c}$ showed that the proposed model appears to have a rather positive effect on the organisation of ideas in factual paragraphs produced by EFL students. The word count in analysis $1 \mathrm{c}$ tallied 127 words. Generally, taking into account the task topic, it would have been expected to have more than one type of holiday accommodation included and developed in analysis 1c. There were some internal links between ideas, but, in general, this piece of writing was too short and not properly developed, and some themes chosen by the writer lacked coherence in relation to the task topic "types of holiday accommodation." For instance, "[...] variety of holiday accommodation [...]" in rheme 1 was developed through a zigzag pattern in theme 1 ("The most common places"). Similarly "Hotels" in rheme 2 was subsequently developed through a zig-zag pattern "those places places" in theme 3, and a continuous pattern "Some of them" in theme 4. Then, a new theme "you" (theme 6) was brought in from outside the text and developed using a continuous pattern. This is shown in Table 7 below.

Table 7. Analysis of sample $1 \mathrm{c}$

\begin{tabular}{|c|c|c|c|}
\hline No & Theme & Rheme & Pattern \\
\hline 1 & $\begin{array}{l}\text { Depending on the kind } \\
\text { of tourism like, you }\end{array}$ & $\begin{array}{l}\text { could find a huge variety of holiday accommodation } \\
\text { for all tastes and budgets. }\end{array}$ & \\
\hline 2 & $\begin{array}{l}\text { The most common } \\
\text { places }\end{array}$ & $\begin{array}{l}\text { are Hotels, where people can rest without having } \\
\text { in mind what to cook or What's the time; }\end{array}$ & \\
\hline 3 & those places places & $\begin{array}{l}\text { offer services that can start from a place to sleep, to a luxury } \\
\text { suite with all the premium equipment you can imagine. }\end{array}$ & zig-zag \\
\hline 4 & $\begin{array}{l}\text { In adittion, some } \\
\text { of them }\end{array}$ & $\begin{array}{l}\text { offer plans for their guests that can include breakfast, } \\
\text { meals and snacks too. }\end{array}$ & Continuous \\
\hline 5 & $\begin{array}{l}\text { Having that in, } \\
\text { mind if you }\end{array}$ & want to decide where to spend your holidays firstly & external theme \\
\hline 6 & You & $\begin{array}{l}\text { must have clear the kind of tourism you like or want; } \\
\text { defining if you want to rest, to meet new places or to } \\
\text { experience new things. }\end{array}$ & Continuous \\
\hline
\end{tabular}


Conversely, analysis $2 \mathrm{c}$ appeared to have better cohesion and coherence because of the larger amount of embedded internal links in the text. The word count in analysis $2 \mathrm{c}$ tallied 166 words. Compared to analysis $1 \mathrm{c}$, analysis $2 \mathrm{c}$ was longer, had more internal links, and included more variety of content regarding themes. For example, an item in rheme 1 ("people") was linked to themes 2-3 through a zigzagcontinuous pattern. Four types of holiday accommodation options were introduced in rheme 3 and later split into themes 4 ("Hotels"), 7 ("Apartments for rent"), 10 ("camping"), and 13 ("Hostals"). The first split was developed through two consecutive zigzag patterns in rhemes 4-5. The second split then followed a similar pattern linking rhemes 7-8. The third split, "camping" (theme 10) was developed through two continuous patterns (themes 11-12). The last split "Hostals" in theme 13 was partly linked to theme 14 "The main disadvantage of this type of accommodation" which subsequently showed a zigzag pattern i.e. "bathroom" in rheme 14- theme 15, as shown in Table 8 below.

Table 8. Analysis of sample 2c

\begin{tabular}{|c|c|c|c|}
\hline No & Theme & Rheme & Pattern \\
\hline 1 & $\begin{array}{l}\text { Kinds of holiday } \\
\text { accommodation }\end{array}$ & are a difficult choice for people. & \\
\hline 2 & When people & decides where to spend their holidays, & zig-zag \\
\hline 3 & They & $\begin{array}{l}\text { usually choose between the next four options: hotels, } \\
\text { apartments, camping and hostals. }\end{array}$ & Continuous \\
\hline 4 & Hotels & $\begin{array}{l}\text { offer many services for their customers such as } \\
\text { restaurants, bars, swimming pools, etc. }\end{array}$ & split 1 from rheme 3 \\
\hline 5 & \begin{tabular}{|l|l} 
However, the \\
quantity of services
\end{tabular} & is directly related to its cost. & zig-zag \\
\hline 6 & Its cost & depends on the number of stars. & zig-zag \\
\hline 7 & Aparments for rent & $\begin{array}{l}\text { provides least services in comparisson with hotels while } \\
\text { giving more privacy. }\end{array}$ & \\
\hline 8 & Least services & mean that sometimes people need to cook their own food. & zig-zag \\
\hline 9 & Cooking & is not ideal when you want to rest. & zig-zag \\
\hline 10 & $\begin{array}{l}\text { The next option, } \\
\text { camping, }\end{array}$ & is the cheapest kind of accommodation but & split 3 from rheme 3 \\
\hline 11 & It & is not a comfortable option. & Continuous \\
\hline 12 & Sometimes it & involves sleeping outdoor in cold conditions. & Continuous \\
\hline 13 & \begin{tabular}{l|l} 
On the other hand, \\
Hostals
\end{tabular} & $\begin{array}{l}\text { have reassonable prices while giving people the } \\
\text { opportunity to meet more human beings. }\end{array}$ & split4 from rheme 3 \\
\hline 14 & \begin{tabular}{|l|l} 
The main \\
disadvantage of this \\
type of accommodation
\end{tabular} & is the lack of private bathroom. & $\begin{array}{l}\text { partially external } \\
\text { theme }\end{array}$ \\
\hline 15 & A bathroom & may have to be share between many people. & zig-zag \\
\hline
\end{tabular}


Once again, the word limit in the latter analysis was larger, so this gave the student more opportunity to develop ideas better and include more types of holiday accommodation.

\section{Teachers' Survey Results}

The table below shows the tabulation of the peer survey results according to the following coding. Cohesion and coherence: 1) very poor, 2) poor, 3) acceptable, 4) good, or 5) very good. Categories for open-ended reasons behind assessment: 1) organisation of ideas, 2) clear focus on development of ideas, 3) linking between ideas through cohesive devices, 4) other reasons.

Table 9. Tabulation teachers' survey results

\begin{tabular}{|lcccc}
\hline & Sample 1a & Reason & Sample 2a & Reason \\
\hline Teacher 1 & 4 & 2 & 4 & 1 \\
\hline Teacher 2 & 3 & 2 & 4 & 2 \\
\hline Teacher 3 & 4 & 4 & 5 & 3 \\
\hline Teacher 4 & 5 & 3 & 4 & 3 \\
\hline Sample 1b & Reason & Sample 2b & Reason \\
\hline Teacher 5 & 3 & 2 & 4 & 1 \\
\hline Teacher 6 & 4 & 2 & 2 & 4 \\
\hline Teacher 7 & 4 & 1 & 5 & 1 \\
\hline Teacher 8 & 3 & 2 & 4 & 2 \\
\hline Teacher 9 & 2 & Reason & Sample 2c & Reason \\
\hline Teacher 10 & 3 & 2 & 4 & 2 \\
\hline Teacher 11 & 3 & 1 & 4 & 1 \\
\hline Teacher 12 & 3 & 3 & 4 & 1 \\
\hline
\end{tabular}

Samples 1a-2a. A breakdown of the survey results for samples 1a2 a showed that two out of four teachers (i.e. teachers 2 and 3 ) assessed the piece of writing after the teaching intervention slightly better in terms of clearer focus and usage of linking devices. One teacher saw no improvement, and another one (teacher 4 ) deemed the paragraph before the implementation better because of its usage of linking devices. The figure below shows a visual representation of these results. 


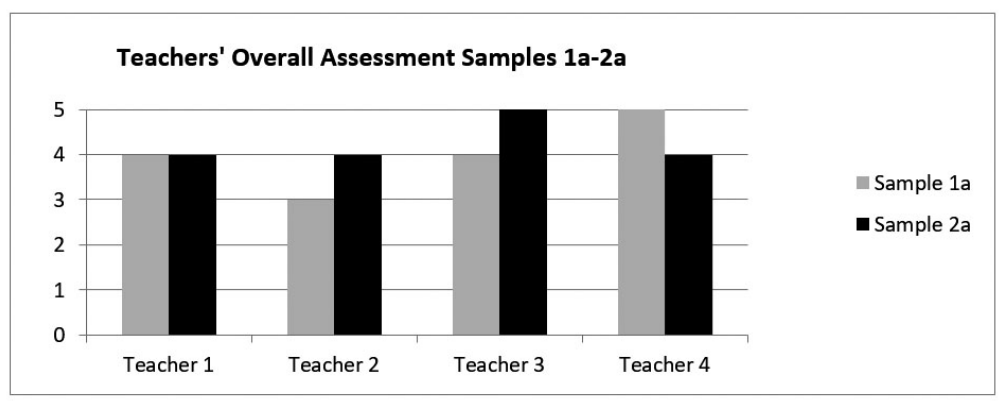

Figure 4. Teachers' overall assessment samples 1a-2a

These results seem to partly contradict those from the qualitative thematic patterns analyses $1 \mathrm{a}-2 \mathrm{a}$, and seem to indicate that the proposed model is not fully effective for the teaching of factual EFL writing. It appears as though students' writing performance is not always likely to improve solely as a result of the implementation of thematic patterns in paragraphs, and that cohesion and coherence can also be based on the linkage of ideas through cohesive devices.

Samples $1 b-2 b$. The survey results for samples $1 b-2 b$ showed that three out of four teachers (teachers 5, 7 and 8) assessed the piece of writing after the teaching intervention slightly better in terms of organisation of ideas and clearer focus. One teacher (teacher 6) saw regress because of other reasons, in particular, the lack of coherence in relation to the wrong chronological order in which the seasons were introduced in the text, and the impression that some subtopics in the paragraph such as "snow" were not directly related to the main topic of the seasons. The figure below shows a visual representation of these results.

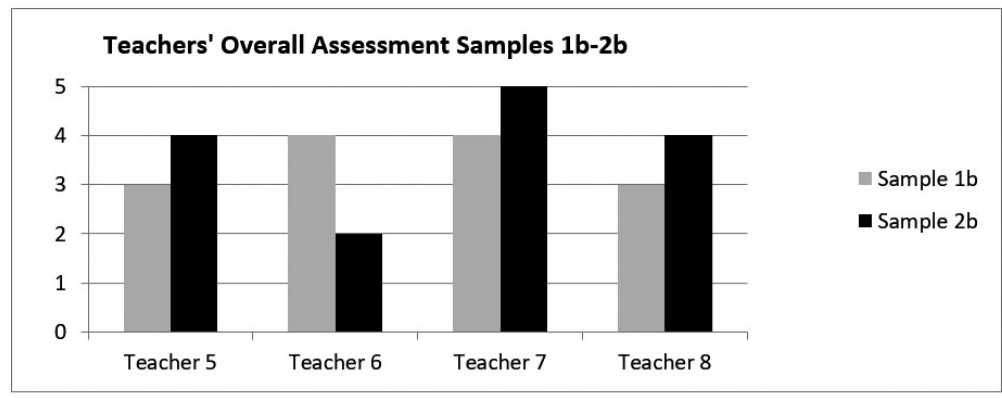

Figure 5. Teachers' overall assessment samples $1 \mathrm{~b}-2 \mathrm{~b}$ 
These results seem to corroborate those from the qualitative thematic patterns analyses $1 b-2 b$, in which the proposed model based on thematic patterns analyses and subsequent writing is somewhat effective for bringing organisation and clear focus to ideas within factual paragraphs. However, students may need to thread carefully around the logic behind the introduction of ideas, particularly, when chronological order is concerned.

Samples $1 \mathrm{c}-2 \mathrm{c}$. The survey results for samples $1 \mathrm{c}-2 \mathrm{c}$ showed that four out of four teachers (i.e. teachers 9, 10,11 and 12) assessed the piece of writing after the teaching intervention slightly better primarily in terms of organisation of ideas, and secondarily in relation to clarity of focus on ideas. The figure below shows a visual representation of these results.

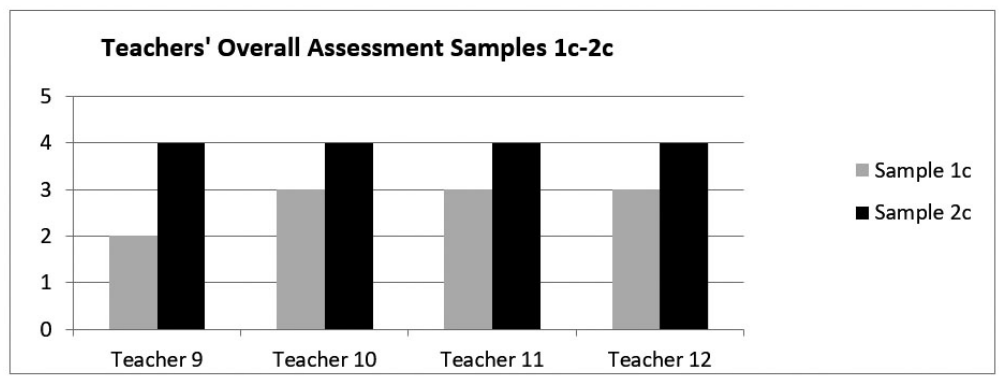

Figure 6. Teachers' overall assessment samples $1 \mathrm{c}-2 \mathrm{c}$

These results seem to validate those from the qualitative thematic patterns analyses $1 \mathrm{c}-2 \mathrm{c}$, where the proposed model appears to have a rather positive effect on the organisation of and focus given to ideas in factual paragraphs.

Mode before and after teaching intervention. A close look at the mode within reasons given by teachers for their overall assessment of pieces of writing in the survey reveals that the value that occurred most frequently among the set of answers in the paragraphs before the model implementation was 2 (i.e. clear focus on development of ideas), whereas the one afterwards was 1 (i.e. organisation of ideas), as shown in the table below. 
Table 10. MODE before and after teaching intervention

\begin{tabular}{|c|c|c|c|c|c|c|c|c|c|c|c|c|c|c|}
\hline & & & & & & & & & & & & & $\begin{array}{l}\text { MODE } \\
\text { (the most } \\
\text { common) }\end{array}$ & $\begin{array}{c}\text { RANGE } \\
\text { (measure } \\
\text { of } \\
\text { dispersion) }\end{array}$ \\
\hline $\begin{array}{c}\text { Reason } \\
\text { Samples } \\
\text { 1a, 1b \& } \\
\text { 1c }\end{array}$ & 2 & 2 & 4 & 3 & 2 & 2 & 1 & 2 & 2 & 1 & 3 & 1 & & \\
\hline Arranged & 1 & 1 & 1 & 2 & 2 & 2 & 2 & 2 & 2 & 3 & 3 & 4 & 2 & 3 \\
\hline $\begin{array}{l}\text { Reason } \\
\text { Samples } \\
2 \mathrm{a}, 2 \mathrm{~b} \& \\
2 \mathrm{c}\end{array}$ & 1 & 2 & 3 & 3 & 1 & 4 & 1 & 2 & 2 & 1 & 1 & 1 & & \\
\hline Arranged & 1 & 1 & 1 & 1 & 1 & 1 & 2 & 2 & 2 & 3 & 3 & 4 & 1 & 3 \\
\hline
\end{tabular}

In general, it seems as though the majority of teachers, other than one group of teachers (i.e. teachers 1-4), assessed the paragraphs after the intervention slightly better than the paragraphs before the intervention. The mode within the reasons behind the assessments showed that those slight improvements were partly due to a change in the organisation of ideas. Therefore, these results seem to validate those from the qualitative analyses which had shown that the proposed model appears to improve the organisation of ideas in factual paragraphs.

\section{Conclusions}

Overall, this study aimed to investigate the effectiveness of a model for the teaching of EFL writing entailing the application of three thematic patterns (Bloor \& Bloor, 2013) through text analysis tasks.

The results of qualitative analyses showed that the samples after the model implementation seemed to be better developed and included more internal links within the paragraphs. They appeared to have more continuous, zigzag, and split thematic patterns bringing more variety and better organisation to the pieces of writing. Moreover, a sample after the model implementation, which had a shorter word count than its counterpart before the implementation, was deemed more compact and better organised. This could potentially place the proposed model as a useful tool for teachers to help students become more precise and concise when writing within a word limit.

The results of teachers' quantitative assessments tended to confirm those from the qualitative analyses, which had shown that the proposed model appears to aid the organisation of ideas at the paragraph level. However, cohesion and coherence can also be brought into writing via other means such as cohesive devices. Students may need to be careful with how ideas are presented, particularly when chronological order is a main concern e.g. the order in which the seasons occur. 
Therefore, it could be concluded that the implementation of a model based on thematic patterns analysis is somewhat effective for the teaching of factual EFL writing. Such a model has a seemingly positive effect on the writing performance of EFL students in terms of their paragraph cohesion and coherence. The results of this study suggest that giving students practice in recognising different ways of packaging and organising information in texts through text analysis tasks appears to translate into moderately more cohesive and coherent pieces of writing. The results of these analyses appear to confirm Bloor and Bloor's (2013) view that thematic patterns serve as a channel to introduce, package and organise information cohesively and coherently at paragraph level, and also Davies's (1988) idea that integrating reading as the basis for subsequent analysis can develop students' awareness of writing subskills.

Indeed, the results of this research need to be taken with caution, as they are particular to the context in which this study was carried out. For instance, being an action research project, the results here are limited by factors such as data reliability in relation to the researcher's involvement, which means that results could not be generalised to all teaching contexts. The fact that only three students were measured in terms of progress or regress in their writing performance poses major questions in the study. Ideally, if the samples produced by the 12 students before and after the model implementation (i.e. 24 samples in total) had been analysed, this would have made the data more robust.

Future studies could perhaps enquire further into the application of the same model to groups of students in other contexts e.g. young learners. Also, it would be worth gauging successive impact of the model on students' writing performance in subsequent writing tasks at later stages within the action research cycle. Researchers could potentially explore the role of L1 in relation to the model application and the distance between L1 and L2. For instance, would research on the application of the model with Chinese and Arabic EFL students produce similar results?

Ultimately, the outcomes of this study can only be seen as a further alternative to the never-ending process of teaching-learning EFL writing, and as a minor contribution to Rojas's (2014) idea of narrowing down the gap between the role of linguistics theory and its applicability to the EFL classroom. 


\section{References}

Bell, J. (2010). Doing your research project (5th ed.). Berkshire: Open University Press - McGraw-Hill Education.

Bloor, T. \& Bloor, M. (2013). The functional analysis of English (3rd ed.). Oxon: Routledge.

Cheng, F. W. (2008). Scaffolding language, scaffolding writing: a genre approach to teaching narrative writing. Asian EFL Journal, 10(2), 167-191.

Connor, U., \& Farmer, M. (1990). The teaching of topical structure analysis as a revision strategy for ESL writers. In B. Kroll (Ed.), Second language writing: Research insights for the classroom, (pp. 126-139). New York: Cambridge University Press.

Cumming, A. \& Riazi, A. (2000). Building models of adult secondlanguage instruction. Learning and Instruction, 10(1), 55-71.

Davies, F. (1988). Designing a writing syllabus in English for academic purposes: Process and product. In P. Robinson (Ed.), Academic writing: Process and Product, ELT Documents, 129 (pp. 130-142).

Denscombe, M. (2010). The good research guide for small-scale social research projects (4th ed.). Berkshire: Open University Press McGraw-Hill Education.

Eggins, S. (2004). An introduction to systemic functional linguistics (2nd ed.). London: Continuum.

Flowerdew, L. (2000). Using a genre-based framework to teach organizational structure in academic writing. ELT Journal, 54(4), 369-378.

Halliday, M.A.K. \& Matthiessen, C. (2004). An introduction to functional grammar (3rd ed.). London: Arnold.

Horner, B. \& Min-Zhan, L. (1999). The birth of basic writing. Urbana, IL: National Council of Teachers of English.

Keck, C. (2006). The use of paraphrase in summary writing: a comparison of L1 and L2 writers. Journal of Second Language Writing, 15(4), 261-78.

Kongpetch, S. (2006). Using a genre-based approach to teach writing to Thai students: a case study. Prospect, 21(2), 3-33.

Olivas, M. \& Li, C. (2006). Understanding stressors of international students in higher education: What college counsellors and personnel need to know. Journal of Instructional Psychology, 33, 217-222. 
Rojas, S. (2014). Linguistics at university Level: The challenge of its learning process in a program of bilingual education. GIST Education and Learning Research Journal, 8 (January-June), 156-170.

Sidaway, R. (2006). The genre-based approach to teach writing. In English!, Spring, 24-27.

Wall, D., Nickson, A., Jordan, R., Allwright, J., \& Houghton, D. (1988). Developing student writing - A subject tutor and writing tutors compare points of view. In P. Robinson (Ed.), Academic Writing: Process and Product, ELT Documents, 129, (pp. 117-129).

Woodrow, L. (2006). Enlish in academic setting: A postgraduate course for students from non-English speaking backgrounds. In Snow \& Kamhi-Stein (Eds.), Developing a new course for adult learners (pp. 197-218). TESOL Publications.

Yuan-Shan, C. and Shao-Wen, S. (2011). A genre-based approach to teaching EFL summary writing. ELT Journal, 1-9. doi:10.1093/elt/ ccro61.

Yu, G. (2009). The shifting sands in the effects of source text summarizability on summary writing. Assessing Writing, 14(2), 116-37.

\section{Texts adaptations in the Literature Review section}

Examples of continuous and split thematic patterns. Texts adapted from: Royal Botanic Gardens Kew - 'Marianne north and the North Gallery, Kew'. Key Information Sheet K9.

Example of split thematic pattern. Text adapted from Doerner, M. (1949). The Materials of the Artist and Their Use in Painting: with notes on the techniques of the old masters. New York: Mariner Books.

\section{Author}

*Ender Velasco Tovar holds a Cambridge CELTA and DTELLS, and a MA in Applied Linguistics and TESOL. He has over 10 years teaching experience in various contexts in the UK and Colombia. He has written for specialized journals such as CALJ, and has recently published a book entitled $A$ Brief Introduction to ELT Methodology. His research interests include: the application of text analysis to the EFL classroom, EFL writing and ELT methodology. 